\title{
The Suffering Moses in the Pentateuch and Psalms
}

\author{
ECKart OtTo (LudWig MaXimilian University, Munich / \\ University of Pretoria)
}

\begin{abstract}
The article shows the prophetic profile of Moses from the perspective of the "final text" of Deuteronomy especially in Deut 4 and Deut 2930. In Deut 30:1-10, Moses announces the circumcision of hearts. Moses' song in Deut 32 confirms his message of doom and final salvation for the people of Israel. It solves the question of collective salvation of the people by a kind of canonical theology, quoting as a subtext Prophets, Psalms and Wisdom Literature. However, Deuteronomy has no answer to Moses' fate of suffering death. He has to die, so that instead of him the written Torah can accompany the people on their way into the Promised Land. Moses' fate of suffering death is not at all over because Pss 90-92 function also as a subtext for Moses' individual fate, developing a perspective of salvation for him as a kind of subtext for the Moses narrative in Deuteronomy.
\end{abstract}

KEYWORDS: Suffering, Moses, Deuteronomy, Pentateuch, Psalms

The Pentateuch ends with two catastrophes namely a collective one announced by YHWH in Deut 31:16-21, predicting doom and annihilation of the people, and an individual catastrophe for Moses, YHWH's arch-prophet, who had to die before the people could cross the river Jordan. Is there a connection between these two perspectives of an individual and a collective tragedy? Furthermore, what have these Pentateuchal perspectives to do with the book of Psalms? It is my thesis in this contribution that the divine announcement of annihilation of the people finds a positive solution in the postexilic "Fortschreibung" (re-lecture) of the book of Deuteronomy ${ }^{1}$ in Moses' farewell song in Deut $32,{ }^{2}$ which is an "amphibolical psalm," alluding to and quoting many texts of doom and salvation from the Prophets and Psalms. In the end, it is the canon itself that provides an

* Submitted: 17/02/2020; peer-reviewed: 06/05/2021; accepted: 10/05/2021. Eckart Otto, "The Suffering Moses in the Pentateuch and Psalms," Old Testament Essays 34 no. 1 (2021): 240 - 253. DOI: https://doi.org/10.17159/2312-3621/2021/v34n1a13.

1 Cf. Eckart Otto, Deuteronomium 1,1-4,43 (vol. 1 of Deuteronomium 1-11; HTKAT; Freiburg: Herder, 2012), 248-280.

2 Cf. Eckart Otto, "Singing Moses: His Farewell Song in Deuteronomy 32," in Psalmody and Poetry in Old Testament Ethics (ed. Dirk J. Human; LHBOTS 572; London: T \& T Clark, 2012), 169-180; id., Deuteronomium 23,16-34,12 (vol. 2 of Deuteronomium 12-34; HTKAT; Freiburg: Herder 2017), 2130-2203. 
answer of salvation to YHWH's prediction of doom for the people. However, the Pentateuch has no answer to Moses' fate of a premature death in Moab. It is the book of Psalms in its late theocratic redaction of Pss 90-92, which offers an answer to the question of Moses' fate. To narrate Moses' premature death was, to the postexilic Pentateuch, a theological necessity for the hermeneutics of the Torah. Moses had to die so that the Torah could "resurrect" into the written text of the Torah, which accompanied the people on their way into the Promised Land after crossing the river Jordan. Nevertheless, the reader of the Torah wonders if God himself was not interested in the individual fate of his servant, and if there was a theological necessity for his suffering and death.

The psalm in Deut 32 was incorporated into the book of Deuteronomy in order to solve the fundamental theological problem of the interpretation of not only Deuteronomy, but indeed all of the Torah, that the last words of God in the Pentateuch paint a picture of the annihilation of his people (Deut 31:16-21). ${ }^{3}$ Moses' song solves the theological predicament that the Torah would in its entirety become senseless if it merely said that the people would fail and would be destroyed by God himself. The kerygma of Moses' psalm, however, restores hope in that it promises salvation for the people following the predicted doom. This corresponds exactly to Moses' own prophecies in the book of Deuteronomy. The frame of the book of Deuteronomy does not only interpret Moses as a prophet (Deut 18:18; 34:10-12). Indeed, his prophecies in Deut 4 and 29 show him as an acting prophet of doom and salvation. ${ }^{4}$ As stated in Deut 4:25-28,

When you will bear children and grandchildren, you will run headlong to your doom, and make any kind of idol and do evil in the eyes of YHWH, your God, provoking him to anger - I call today heaven and earth as witnesses against you - then you will perish from the land that you are crossing the Jordan to possess. You will not live there for long, but you will be destroyed. YHWH will scatter you among the nations and only a few of you will survive among the nations, to which YHWH will drive you. There you will worship man made deities, made out of wood and stone, which cannot hear or eat or smell.

Nonetheless, this doom will be followed by salvation for the remnant, surviving in exile. See Deut 4:29-31 which says,

But from there you will seek YHWH, your God, and you will find him, if you look for him with all your heart and with all your soul. In your

3 For the exegetical context of these verses, cf. Eckart Otto, Das Deuteronomium im Pentateuch und Hexateuch: Studien zur Literaturgeschichte von Pentateuch und Hexateuch im Lichte des Deuteronomiumrahmens (FAT 30; Tübingen: Mohr Siebeck, 2000), 175-211; idem., Deuteronomium 23,16-34,12, 2078-2129.

4 See Otto, 1,1-4,43, 274-280. 
distress all these words will find you. At the end of the days you will return to YHWH and you will listen to his voice, for YHWH is a merciful God, he will not abandon or destroy you or forget the covenant with your forefathers, which he confirmed to them by oath. ${ }^{5}$

After the promulgation of his interpretation of the laws, given at Sinai in Deut 12-26, Moses confirms his prophecy of Deut 4:25-31 in Deut 29:21-28:6

The children who follow you and later generations after you: foreigners, who come from distant lands, when they will see the calamities that have fallen on the land and the diseases with which YHWH has afflicted it, will say: "All its land is a burning waste of salt and sulphur, nothing planted, nothing sprouting, no vegetation is growing on it. It is like the destruction of Sodom and Gomorrah, Adma and Zebojim, which YHWH has overthrown in fierce anger." And all the nations will ask: "Why has YHWH done this to this land? Why this fierce, burning anger?" Then it will be said, "It is because they abandoned YHWH's covenant, the God of their fathers, the covenant he had made with them when he brought them out of Egypt. For they went and served deities that they had not known and he had not given them. That is why YHWH's anger burned against this land, so that he brought on it all the curses that were written in this book. In furious anger and in great wrath YHWH uprooted them from their land and thrust them into another land, as it is today."

As in Deut 4:25-31, this prophecy also contains a turning point from doom to salvation. Consider Deut 30:1-10:

So it shall be, when all these words have come upon you, the blessings and the curses which I set before you, and you will let them into your heart among the nations, where YHWH your God has banished you, and you will return to YHWH your God, and will obey his voice according to all that I commanded you today, you and your offspring with all your heart and with all your soul, then YHWH will turn around your captivity and have compassion upon you and will return and gather you from all the nations, where YHWH, your God, has banished you.

5 For the literary history and theology of the prophetic message of Moses in the postexilic Deut 4, cf. Georg Braulik, Die Mittel deuteronomischer Rhetorik erhoben aus Deuteronomium 4,1-40 (AnBib 68; Rome: Biblical Institute Press, 1978), passim; Otto, 1,1-4,43, 508-592.

6 For the literary context of these verses, cf. Otto, Das Deuteronomium, 138-155; idem., Deuteronomium 23,16-34,12, 2050f., 2061-2066; cf. also Ernst Ehrenreich, Wähle das Leben! Deuteronomium 30 als hermeneutischer Schlüssel zur Tora (BZAR 14; Wiesbaden: Harrassowitz, 2011), 95-101. 
Deuteronomy 4:31 gives the theological reason for this turning point from doom to salvation by alluding to the formula of grace in Exod 34:6, "YHWH is a merciful God of compassion." Again and again, the frame of Deuteronomy alludes to Deut 4:31 together with 4:37 (see for example Deut 8:16; 9:26-27; $10: 10 ; 11,8-9$ in connection with Deut 10:14-15), so that the Mosaic prophecy in Deut 4:25-31.37 functions as a subtext for the frame of Deuteronomy in Deut 5-11 (as Deut 29:22-30:10 does for Deut 29-34). The frame of Deuteronomy is to be read with Moses' prophecies as its subtext underlying the parenesis with a clear message namely that there will be doom and suffering for the people but this will not be the last word because YHWH is a merciful God. The riddle-verse in Deut 29:28 is part of this amphibolic character of the Mosaic parenesis:

The secret things belong to YHWH, our God, but the things revealed belong to us and our children for ever, in order to do all the words of this Torah.

This verse stands at the end of the prophecy of doom in Deut 29:21-27 and at the beginning of the prophecy of salvation. Moses, not his addressees, ${ }^{7}$ is speaking here, but he identifies with his addressees, as he also did in Deut 12:8. The verse differentiates between the individual and the collective fates, reflecting a postexilic attitude to retribution. ${ }^{8}$ Other than the fate of doom and salvation for the people, the reward and punishment in the case of Moses as an individual remains a secret that belongs to God. The fate of God's servants, which does not fit the strict doctrine, remains a secret (as when prophets were imprisoned or killed for delivering God's messages, cf. 2 Chron 16:10; 24:20-22). ${ }^{9}$ In contrast, the collective fate of the people is for Deut 29:28 not a secret, but is revealed in the book of Deuteronomy. The verse reflects the amphibolic character of the text of Deuteronomy, saying that the meaning of the text is not hidden and that this includes the subtext of Moses' prophecies since this verse is found in the middle of the prophecy and at a turning point between the prophecy of doom and salvation. Moses' prophecy, underlying the text of Deuteronomy's frame, aims at the message that suffering from annihilation will not be the last word of Deuteronomy for the people of the future. Their hearts will be circumcised (Deut 30:6) if they keep to the Torah.

7 Cf. also Dominik Markl, Gottes Volk im Deuteronomium (BZAR 18; Wiesbaden: Harrassowitz, 2012), 104-107.

8 See Gershon Galil, “'The Secret Things Belong to the Lord Our God' (Deut 29:29): Retribution in the Persian Period," Transeuphratène 39 (2010): 89-94.

9 See Sara Japhet, 2 Chronik (HTKAT; Freiburg/Basel/Wien: Herder, 2003), 303305. 
At any rate, the beat of a kettledrum follows in Deut 31:16-18. YHWH himself begins to speak in order to confirm the prophetic words of his prophet Moses. However, God confirms only Moses' prophecies of doom,

YHWH said to Moses, "You are going to rest with your fathers, and these people will soon prostitute themselves to foreign deities of the land, where they are going to. They will forsake me and break the covenant I made with them. On that day I shall become angry with them and forsake them. I shall hide my face from them, and they will be destroyed. Many evils and disasters will come upon them, and at that day they will ask, 'Are not these evils come upon us, because our God is not with us?' And I shall hide my face on that day because of all their wickedness in turning unto other Gods.

There is not a single word of salvation and redemption, as Moses had announced it, in God's address to Moses. Does this imply that YHWH falsified Moses' prophecies? After YHWH has predicted a future catastrophe for the people, he summons Moses to write down the book of Deuteronomy again, now including Moses' song in 32:1-43 as a witness against the people. Again, the poem begins with the announcement of doom for the people. Deut 32:5-6, 15 states that:

They have acted corruptly towards him. To their shame, they are no longer his children but a warped and crooked generation. Is this the way you repay YHWH, o foolish and unwise people? Jeshurun grew fat and kicked, filled with food; he became heavy and sleek. He abandoned the God who made him and rejected the Rock, his saviour. They made him jealous with their foreign deities and angered him with their detestable idols. They sacrificed to demons, which are no gods.

However, in this Song of Moses we find the same phenomenon as in the other parts of the frame of Deuteronomy. It is to be read on two levels as an amphibolia. Behind the text on the surface exists a second text, which is formed by Moses' quotations and allusions to the books of the Prophets, Psalms and Wisdom. In other parts of Moses' speeches, his prophecies of doom and salvation in Deut 4 and 29 constitute a kind of subtext to which Moses alludes again and again. Here it is the whole canon which forms the subtext. ${ }^{10}$ In Deut 32:1, Moses quotes Isa 1:2,

Listen, o heavens, and I will speak; hear, o earth, the words of my mouth.

10 Cf. Eckart Otto, "Moses Abschiedslied in Deuteronomium 32: Ein Zeugnis der Kanonsbildung in der Hebräischen Bibel," in Die Tora: Studien zum Pentateuch: Gesammelte Aufsätze (ed. Eckart Otto; BZAR 9; Wiesbaden: Harrassowitz, 2009), 641678; idem., Deuteronomium 23,16-34,12, 2173-2196. 
Listen, o heaven, hear, o earth! For YHwH has spoken, "I reared children and brought them up, but they have rebelled against me. The ox knows his master, but my people does not understand."

Beginning the song with a quotation of Isa 1:2 means that not only the directly quoted words are relevant for the interpretation of the song, but also the literary context of the quotations, which constitutes a subtext for the text of Moses' song. Furthermore, the subtext of Deut 32:1 explains that what will follow in this song will be a complaint by God and an announcement of doom as a witness against the people, as Deut 31:19 has already said. This subtext of Deut 32:1 becomes explicit in the text of Moses' song in Deut 32:18,

Of the Rock that begat you, you are unmindful, and have forgotten God, who formed you.

On the other hand, the subtext for the next verse (Deut 32:2) already delivers another melody and a message of salvation,

My teaching will fall like rain and my words descend like dew, like showers on new grass, like abundant rain on tender plants.

This verse alludes to Mic 5:7:

The remnant of Jacob will be in the midst of many nations like dew from YHWH, like showers on the grass.

The context of this verse in Mic 5 is a prophecy of salvation that the remnant of Jacob will be like a young lion among the flocks of sheep:

Your hand will be lifted up upon your adversaries, and all your enemies will be cut off (Mic 5:9).

Micah 5:15 refers to the motif of Deut 32:27-29 namely that the unwise nations without understanding will provoke YHWH's anger.

Already the first two verses of Moses' song, read in the horizon of their subtexts in Isaiah and Micah, clarify that there will be doom brought upon the offspring of Moses' addressees. Nevertheless, there will also be salvation-just as Moses' prophecies announced in Deut 4:25-31 and 29:21-30:10, a remnant will be saved by YHWH. The subtext of Moses' song hints his addressees, already in the beginning, that a lack of understanding among the nations will evoke God's anger, so that he will bring doom over them. The text of Moses' song will confirm this. In contrast to the subtext, Moses' song seems, at first glance, only to confirm YHWH's anger with his people that will result in cruel punishment and suffering. Deuteronomy 32:19-20 outlines the approaching suffering of the people. Again however, the prophetic subtext contains hints in the direction of salvation, where the text of Moses' song speaks of doom. In Deut 32:15 and 17 the epitheton Eloha, which is rarely used in the HB, alludes to Isa 43:10, which 
corresponds to Deut 32:29, the pivotal monotheistic point in Moses' song. The context of Isa 43:10 proclaims YHWH as the only God and saviour:

I, even I, am YHWH, and beside me there is no saviour. I have declared and I have saved, and I have shewed, when there was no strange deity among you. Therefore you are my witnesses, says YHWH, that I am God (Isa 43:11-12).

The term Jeshurun in Deut 32:15 also connects Moses' song with the hymnic frame of his blessings in Deut 33:5, 26 and with Isa 44:2, the only texts where this epitheton is used in the HB:

So says YHwH, who formed you from the womb, who will help you.

Do not be afraid, o Jacob, my servant, and you Jeshurun, whom I have chosen.

Whereas Deuteronomy 32:22 quotes Jer 15:14 and Ps 86:13:

A fire is kindled im my anger and will burn unto the lowest underworld and will consume the earth with her increase and set on fire the foundations of the mountains. of doom:

At first glance, the subtext in Jer 15:14 seems to underline this prophecy

And I shall make you the slave of your enemies in a land that is unknown to you, for a fire is kindled in my anger, which will burn upon you.

However, the next verse, Jer 15:15, already opens up a perspective of hope for the people:

You know, o YHWH, remember me and visit me, and revenge me of my persecutors. Do not take me away. Put off your anger. You know that for your sake I have suffered rebuke.

Deuteronomy 32:22 also alludes to Ps 86:13:

Great is your mercy toward me. You have delivered my soul from the lowest underworld.

Furthermore, the subtext for Deut 32:24 is Mic 7:7, where the motif of the snake, which in Deut 32:24 is a motif of doom, functions as a motif of hope. Therefore, when the text of Moses' song speaks of God's anger and annihilation of the people, Moses' addressees realise based on the subtext that this will not be God's last word. The subtext of Ps 86:13 explains the turn from doom to salvation by means YHWH's mercy, exactly as Moses did in his prophecy in Deut 4:31 referring to Exod 34:6 as a subtext. Indeed, in Deut 32:26-27, the text moves from doom to salvation on the surface of the text (read without its subtext) 
in a rather unspectacular way, using a theological argument taken from Deut 9:1$6^{11}$ to give reasons for this change in YHWH's mind and so within the text of Moses' song:

I shall scatter them and I shall blot out their memory from mankind. But I shall dread the taunt of their enemy lest the adversary misunderstand and say: Our hand has triumphed, YHWH has not done all this (Deut 32:26).

Deuteronomy 9:5 also states that:

It is not because of your righteousness or your integrity that you are going to take possession of their land, but on account of the wickedness of these nations YHWH will drive them out before you.

In Deut 32:27, the enemies who scatter the people make the mistake of claiming to be the subjects of this scattering and it is for this reason that YHWH will scatter them. The pivotal verse of Moses' song in line with Deut 32:26 is Deut 32:39:

See now that I myself am He. There is no God besides me. I put to death and I bring to life, I wound and I shall heal, neither is there anyone who can deliver out of my hand.

This verse quotes Isa 43:10-13 and now text and subtext merge and become one text:

You are my witness, declares YHwH, and my servant that I haven chosen, so that you know and believe me and understand that I am He. Before me no god was formed, nor will there be one after me. I, even I, am YHWH, and apart from me there is no saviour. I have revealed and saved and proclaimed, I, and not a foreign deity among you. You are my witnesses, says YHWH, that I am God, from ancient times I am He. No one can deliver out of my hand. When I act, who can reverse it? ${ }^{12}$

On the surface of the text of Moses' song, we find misunderstanding on the part of the nations, which do not realise that it is not them but YHWH who is punishing his people by scattering them. The subtext of the song gives a deeper reason for the salvation namely that it is YHWH's mercy that is saving the offspring of Moses' addressees.

11 Cf. Eckart Otto, Deuteronomium 4,44-11,32 (vol. 2 of Deuteronomium 1-11; HTKAT; Freiburg: Herder, 2012), 970-974.

12 For further examples of quotations and allusions to prophetic texts and psalms in Moses' farewell song in Deut 32, see Otto, "Singing Moses," 174-178. 
At this point two remarks will suffice with regard to the hermeneutics of the book of Deuteronomy as part of the Pentateuch:

It is obvious that the framework of Deuteronomy in Deut 1-11 and 2934 cannot be interpreted synchronistically only on the surface of the text without taking into account the subtexts of allusions and quotations as well as the literary contexts of these texts that also form the subtext. The main subtexts of Deut 111 and 29-34 are Moses' prophecies in Deut 4:25-31 and 29:21-30:10. On its surface, Deuteronomy appears to be a legal text consisting of the promulgation of Moses' interpretation of the Sinai legislation of the Torah's Decalogue and Covenant Code. Under this surface, however, Deuteronomy is also a prophetic book, looking ahead to the circumcision of the heart in Deut 30:1-10. For Deuteronomy, its addressees are in a situation "zwischen den Zeiten" (between the periods) - after a catastrophe and before the circumcision of their hearts - so that Moses is exhorting his addressees to follow the commandment of Deuteronomy in order not to lose the final salvation. Moses' prophecies and the prophetic subtext correspond to Moses' characterisation as prophet in Deut 18:18 and 34:10-12.

This prophetically amphibolic character of the frame of Deuteronomy changes to a degree with Moses' farewell song in Deut 32. Now the subtext is no longer constituted by intra-deuteronomic allusions but by allusions and quotations of extra-deuteronomic texts of the canon including the Prophets, Psalms and Wisdom. The deep theological problem in Deuteronomy finds a solution, then, in that Moses' prophecies of salvation are not confirmed by YHWH's announcement of only doom in Deut 31:16-18. The whole canon of the HB confirms Moses' prophecy of salvation and redemption, so that the canon functions as the words of God, confirming Moses' prophecies of salvation.

This settles the question of the collective salvation of the people; but what of the conundrum of Moses' fate as an individual, who has to die before the people enter the Promised Land? In Deut 3:23-29, Moses asks YHWH to be allowed to cross the river Jordan and see the good land beyond the river. ${ }^{13} \mathrm{YHWH}$, however, refuses to fulfil Moses' request since, as Moses says, YHWH is angry with him because of the people. Instead of leading the people into the Promised Land, Moses receives the order to ascend to the top of mount Pisgah. The conversation between YHWH and Moses in Deut 3 is to be seen in the light of the

13 Cf. Simone Paganini, "Die Veränderung der Beziehung zwischen Gott und Mose als Kompositionssignal der deuteronomistischen Erzählung," in Deuteronomium: Tora für eine neue Generation (ed. Georg Fischer, Dominik Markl and Simone Paganini; BZAR 17; Wiesbaden: Harrassowitz, 2011), 147-160; Simone Paganini, Deuteronomio: Nuova versione, introduzione e commento (I.LibBib 5; Milan: Paoline, 2010), 127-129; Otto, Deuteronomium 1,1-4.43, 503-505. 
other conversation between them in the story of the molten calf (Deut 9:25-29), specifically Moses' intercession on behalf of the people, as indicated by the fact that YHWH is addressed as Adonai only here and in Deut 3. In Deut 9, Moses' prophetic intercession saves the people from YHWH's wrath and their annihilation. However, in his own case, Moses cannot change YHWH's mind and save his own life. He has to die because of YHWH's wrath against the people. There are very good legal and theological-hermeneutical reasons for constructing the allegory of the book of Deuteronomy and the Pentateuch such that Moses had to die before entering the Promised Land beyond the river Jordan. The main legal hermeneutical reason for this choice was to explain that Moses' role as mediator of Torah "resurrected" into the written Torah, which accompanied the people on their way into the Promised Land. The theological explanation for Moses' death, in turn, was the rebellion of the people in the episode of the spies in Deut 1:37. ${ }^{14}$ The image of Moses in this story comes near to that of the suffering righteous which is part of his prophetic function in the book of Deuteronomy. Moses obeys YHWH's will, ready to die without any protest against his fate. Different however from the collective fate with its turning point from doom to salvation for Moses' addressees and their offspring, there is no salvation for Moses' individual fate. He has to die, because this is God's will. Therefore, in contrast to the collective perspective of salvation for the people in the Mosaic narrated time and the exilic and postexilic time of narration of the book of Deuteronomy, he does die (Deut 34:1-8). ${ }^{15}$ For Deut 29:28, Moses' individual fate is a secret that belongs to God.

Does this mean that YHWH overrules the individual fate of his prophetic servants and that there is no comfort for them but only for the people? We answer this question in the negative because for Moses also there exists a subtext, found neither in the book of Deuteronomy nor the Pentateuch but in the Psalter. The Pentateuch is theological literature about and for the collective Israel and individuals are treated as a topic in the Pentateuch, only if their fate has some important meaning and function for the people collectively. It is Pss 90-92, as part of the fourth book of the Psalter, that functions as a subtext for Moses' individual fate, developing a perspective of salvation as a kind of subtext for the Moses narrative in Deuteronomy and the Pentateuch. Moses appears only in the fourth book of the Psalter (Pss 90-106; cf. Pss 90:1; 99:6; 103:7; 105:26; 106:16, $23,32)$ - a presence that reflects a theocratic redactional process of the Psalter

14 Cf. Otto, Deuteronomium 1,1-4,43, 396-398.

15 For the hermeneutics of differentiation between time of narration and narrated time in Deuteronomy and the Pentateuch, see Eckart Otto, A Lei de Moisés (BibLoy 61; São Paulo: Edições Loyola, 2011), 99-104; Otto, Deuteronomium 1,1-4,43, 258-263. 
incorporating Pss 90-92 and Ps 95 in Pss $2-100 .{ }^{16}$ This late theocratic redaction of the Psalter already presupposed the post-priestly and post-deuteronomistic redaction of the Pentateuch in Ps 95:7-11; Exod 17:1-7; Num 13-14; 20:2-13 and Deut 12:9-10. All these texts were part of the postexilic redaction of the Pentateuch. ${ }^{17}$ These also include Deut 12:9-10, which was part of the postexilic redaction of the book of Deuteronomy, forming a frame with Deut 25:19 around Moses' promulgation of Torah with the motif of Menuchah. Already in the middle of the 19th century, Georg Volck observed literary connections between Moses' song in Deut 32 and Ps 90. ${ }^{18}$ Deut 32:36 quotes Ps 90:13,

For YHWH will pass sentence for his people, and relent for his servants' sake. Turn back YHWH - how long? - Revoke your sentence and relent for your servants' sake. ${ }^{19}$

Deuteronomy 32:4 alludes to Ps 90:16,

The rock... just and perfect is He.

For perfect is YHWH, my rock.

Moses' song in Deut 32 provides an overview of the entire theocratic redaction of Pss 90-92. For those responsible for the superscript of Pss 90-92 in Ps 90:1, "a tefillah of Moses the man of God," these psalms were Moses' prayer book. Psalm 90 starts with a complaint about the human fate of death and for those who interpreted the psalms as Moses' prayer, it was also Moses who complained about his fated premature death and followed this up with a petition for God's mercy. Psalm 91 responds to this complaint with a divine promise of salvation and, even though he had to die, this is the decisive turning point for Moses. Psalm 92 follows as a psalm of thanksgiving, which differentiates

16 For the theocratic redaction of the fourth book of the Psalter, cf. Martin Leuenberger, Konzeptionen des Königtums Gottes im Psalter: Untersuchungen zur Komposition und Redaktion der theokratischen Bücher IV-V im Psalter (ATANT 83; Zürich: TVZ, 2004), 239-241; Hans-Ulrich Steymans, Psalm 89 und der Davidbund: Eine strukturale und redaktionsgeschichtliche Untersuchung (ÖBS 27; Frankfurt: Peter Lang, 2005), 270-274.

17 Cf. Otto, Das Deuteronomium, 26-93; Reinhard Achenbach, Die Vollendung der Tora: Studien zur Redaktionsgeschichte des Numeribuches im Kontext von Hexateuch und Pentateuch (BZAR 3; Wiesbaden: Harrassowitz, 2003), 308-319.

18 Cf. Guilielmus Volck, Mosis Canticum Cygneum (Nördlingen: Beck, 1861), passim. The author's intention was to demonstrate that, pace Wilhelm M. L. de Wette, Deuteronomy was a Mosaic book. Over 150 years later, this approach is entirely outdated. However, Volck's observation of the literary connections between Moses' song in Deut 32 and Ps 90 remains valid.

19 Psalm 90:13 is a firmly integrated part of the structure of this psalm and the giving text, Deut 32:36, the receiving text. 
between unjust and just people. While the unjust one will be dried up by YHWH's anger, the just one will bear fruit and will proclaim that YHWH, his rock, is just. This proclamation is quoted precisely in Deut 32:4 as an expression of hope for the people.

On the other hand, Moses, praying this psalm, also finds a sign of hope for his own fate. Deuteronomy 32:48-52 ${ }^{20}$ locates Moses' song in the context of YHWH's new announcement of Moses' death after Deut 1:37 and 3:23-28. Deuteronomy 32:48's "on the same day" directly connects Moses' song with the day of his death in order to underline that Moses' death is the context for his song. Situating the song in the context of his death connects the song thematically with Pss 90-92, which deal with the human fate of mortality. Song and narrative in Deut 31-34 do not answer the question of how Moses felt about God's plan to let him die before he could lead his people into the Promised Land on the other side of the river Jordan. He cannot find any comfort in the Pentateuch. The authors of the superscript in Ps 90:1 were of the opinion that he found it in these psalms, meditating on his God-given fate. For these authors, then, Pss 90-92 became the subtext for the Moses' individual life. As God's prophet and mediator of Torah, Moses had to act according to a God-given role. He had to give his life so that the people would have the written Torah as a mediator of God's will. However, is there any answer for his personal life, or could it be that God is uninterested in this aspect? Psalms 90-92 offer an answer as the subtext for Moses' personal life, as Ps 91:4 states:

He will cover you with his feathers and under his wings you trust. His truth will be your shield and your protection.

These late authors (of the fourth book of the Psalter and the book of Deuteronomy as part of the Pentateuch) were aware that the individual life would never entirely merge into the collective life of the people. It is exactly this discrepancy that was the reason for declaring Pss 90-92 as a prayer of Moses. These psalms became a subtext, then, when Moses as a prophet promulgated his farewell song about the fate of doom and salvation for the people and they became a subtext for his individual life as his prayer book, providing the hope that there will be salvation for him even if the Torah offers him nothing but death.

20 For a literary historical exegesis of Deut 32:48-52, cf. Otto, Das Deuteronomium, 222-225; idem., Deuteronomium 23,16-34,12, 2171-2173, 2198- 2200. 


\section{BIBLIOGRAPHY}

Achenbach, Reinhard. Die Vollendung der Tora: Studien zur Redaktionsgeschichte des Numeribuches im Kontext von Hexateuch und Pentateuch. BZAR 3. Wiesbaden: Harrassowitz, 2003.

Braulik, Georg. Die Mittel deuteronomischer Rhetorik erhoben aus Deuteronomium 4,1-40. AnBib 68. Rome: Biblical Institute Press, 1978.

Ehrenreich, Ernst. Wähle das Leben! Deuteronomium 30 als hermeneutischer Schlüssel zur Tora. BZAR 14. Wiesbaden: Harrassowitz, 2011.

Galil, Gershon. "“The Secret Things Belong to the Lord our God' (Deut 29:29): Retribution in the Persian Period." Transeuphratène 39 (2010): 89-94.

Japhet, Sara. 2 Chronik. HTKAT. Freiburg: Herder, 2003.

Leuenberger, Martin. Konzeptionen des Königtums Gottes im Psalter: Untersuchungen zur Komposition und Redaktion der theokratischen Bücher IV-V im Psalter. ATANT 83. Zürich: TVZ, 2004.

Markl, Dominik. Gottes Volk im Deuteronomium. BZAR 18. Wiesbaden: Harrassowitz, 2012.

Otto, Eckart. Das Deuteronomium im Pentateuch und Hexateuch: Studien zur Literaturgeschichte von Pentateuch und Hexateuch im Lichte des Deuteronomiumrahmens. FAT 30. Tübingen: Mohr Siebeck, 2000.

. "Moses Abschiedslied in Deuteronomium 32: Ein Zeugnis der Kanonsbildung in der Hebräischen Bibel." Pages 641-678 in Die Tora: Studien zum Pentateuch: Gesammelte Aufsätze. Edited by Eckart Otto. BZAR 9. Wiesbaden: Harrassowitz, 2009. . A Lei de Moisés. BibLoy 61. São Paulo: Edições Loyola, 2011.

. Deuteronomium 1,1-4,43, Volume 1 of Deuteronomium 1-11. HTKAT. Freiburg: Herder, 2012.

. Deuteronomium 4,44-11,32, Volume 2 of Deuteronomium 1-11. HTKAT. Freiburg: Herder, 2012.

. "Singing Moses: His Farewell Song in Deuteronomy 32." Pages $169-180$ in Psalmody and Poetry in Old Testament Ethics. Edited by Dirk J. Human. LHBOTS 572. London: T \& T Clark, 2012.

. Deuteronomium 23,16-34,12, Volume 2 of Deuteronomium 12-34. HTKAT. Freiburg: Herder 2017.

Paganini, Simone. Deuteronomio: Nuova versione, introduzione e commento. I.LibBib 5. Milan: Paoline, 2010.

. "Die Veränderung der Beziehung zwischen Gott und Mose als Kompositionssignal der deuteronomistischen Erzählung." Pages 147-160 in Deuteronomium: Tora für eine neue Generation. Edited by Georg Fischer, Dominik Markl and Simone Paganini. BZAR 17. Wiesbaden: Harrassowitz, 2011.

Steymans, Hans Ulrich. Psalm 89 und der Davidbund: Eine strukturale und redaktionsgeschichtliche Untersuchung. ÖBS 27. Frankfurt/Main: Peter Lang, 2005.

Volck, Guilielmus. Mosis Canticum Cygneum. Nördlingen: Beck, 1861. 
Otto, "Suffering Moses," OTE 34/1 (2021): 240-253 253

Eckart Otto is Emeritus Professor in the Abteilung für Alttestamentliche Theologie, Theologische Fakultät, Ludwig-Maximilian-Universität, München; and Honorary Professor and Research Associate, Department of Old Testament and Hebrew Scripture, Faculty of Theology and Religion, University of Pretoria. E-mail address: eckart.otto@t-online.de. ORCID ID https://orcid.org/0000-0001-9066-705X 